\title{
Didactic Design Based on Student Responses to Practice Scientific Literacy with Using Marzano Learning Dimensions and Reading Infusion on Momentum Content
}

\author{
Setiya Utari ${ }^{1}$, Rattila Arinal Haque ${ }^{2}$, Saeful Karim³ ${ }^{3}$, Duden Saefuzaman ${ }^{4}$, Muhamad Gina \\ Nugraha $^{5}$, Eka Cahya Prima ${ }^{6}$ \\ $\left\{\right.$ su@upi.edu ${ }^{1}$, rattila@upi.edu ${ }^{2}$, saefulkarim@upi.edu $\left.{ }^{3}\right\}$ \\ Department of Physics Education, Faculty of Mathematics and Science Education, Universitas \\ Pendidikan Indonesia, Bandung, Indonesia ${ }^{1,2,3}$
}

\begin{abstract}
This didactic was designed based on the results of student's responses to scientific literacy (SL) competencies. Some of the student's low responses related to the competencies of explaining scientific phenomena in aspects of building hypotheses, competencies in evaluating and designing the research results on aspects of exploring inquiry questions and competencies of interpreting data and evidence scientifically on the aspects of analyzing and interpreting data and drawing the right conclusion. Didactic design focused on studying momentum related to determining the velocity of the center of the particle system, to prove the validity of momentum conservation law and the relation between rocket speed and emitted gas. The experiment has been tested in the laboratory so it is possible to build tasks and right didactics design so that students have a positive perception in facilitating scientific literacy (SL) competencies.
\end{abstract}

Keywords: Scientific Literacy Competency, Dimensions of Marzano Learning and Reading Infusion

\section{Introduction}

National Science Education Standard (NSES) revealed Scientific Literacy (SL) is the knowledge and understanding of scientific concepts and processes needed by a person in decision making, participation in society and culture, and economic productivity based on curiosity in everyday life experiences. The same phrase put forward by the Organization for Economic Cooperation and Development [1] states SL as the ability to engage with issues related to science, and with science ideas, as a reflective citizen. Someone who has an SL will be willing to be involved in the discourse about science and technology, therefore, competence is needed to explain phenomena scientifically, evaluate and design scientific investigations, and interpret data and scientific evidence. Someone who has an SL will be able to read, understand and be responsible for problems encountered in his life [2]. Therefore SL can be viewed as a provision of competencies that are important for citizens to have so they need to be trained in education, in line with this [3], revealed SL to be a test of learning in science and some country developed and developing SL became the direction of the policy goals of changing the educational curriculum [4]. 
PISA test results are often used as benchmarks to determine the SL of children in the world. Indonesian children's PISA test results are often ranked below, Indonesia took five times the PISA test with the best ranking obtained in 2015 Indonesia ranked 62 out of 70 countries [5]. Since 2015 we have conducted a survey on the SL competency profile of high school students using 628 students, the results show that SL competencies are weak both in explaining scientific phenomena, evaluating and designing investigations and in interfering scientific evidence, this shows that learning in the classroom does not yet provide facilities to train SL, then we develop ways to train SL through the application of Levels of Inquiry (LoI) [6], through a scientific approach [7], through Inquiry and reading Infusion (RI) [8] illustrates that the methods used can improve student LS but are still sporadic. The results of the didactic reconstruction study with the Marzano Learning Dimension (DBM) provide a direction of change, it was found that the difficulty of teaching LS is shown by the lack of initial knowledge students have, perceptions that have not been positive towards training SL and students are not accustomed to using thinking skills in the learning process [9].

Research trains SL by using Marzano's learning dimensions and reading infusion strategies we continue to develop. Related to training SL through the momentum material in high school we found various problems from student responses,including the competence to explain scientific phenomena students still find it difficult to offer hypotheses, in evaluating competence and designing scientific investigations students still find it difficult to propose ways and evaluating how to explore the questions provided scientifically, and in the competence to interpret data and evidence scientifically students still find it difficult to analyze and interpret data and draw appropriate conclusions and identify assumptions, evidence, and reasons in texts relating to science. In the Marzano learning dimension and the Reading infusion design, the didactic strategy was developed by emphasizing the various stages of dimensions that can be expressed in Figure 1.

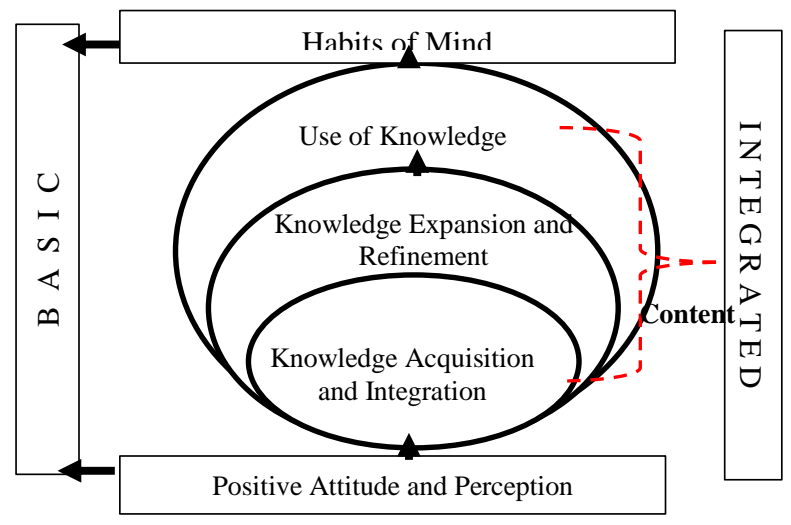

Fig. 1. Marzano Learning Dimensions.

The basis of Marzano's learning dimension is to develop positive attitudes and perceptions from the very beginning to the use of knowledge, the role of the teacher as a facilitator is challenged to ensure students have a positive attitude, students are motivated and not easily frustrated from the acquisition of knowledge to the use of knowledge [10], during the process of the teacher building a habit of mind, therefore the use of a scientific approach, the inquiry process becomes important, in this case, the experiments that are built should not be verification [11]. To prepare the teacher as a facilitator what needs to be done is to provide preliminary knowledge so that students build good communication during acquisition to the use of 
knowledge, The reading infusion strategy was chosen because the teacher can have the flexibility to provide supporting material for the process that will be done, this strategy is seen to smooth the course of the inquiry process [12].

For students to have positive attitudes and perceptions and productive thinking habits, the first thing teachers must do is master the concepts to be conveyed, including being able to explain the contextual application of the material to be carried so that students can feel the benefits of learning this material for what [13]. Teachers need to conduct experiments in the laboratory so that the process of productive thinking habits can be well planned, build scientific processes logically [14], and ensure that things will be done by students have completion steps that can be completed by students, so students are not easily frustrated [15]. As a facilitator ensures that all the work that students will do can be done well. The teacher facilitates students to learn how to learn and learn how to teach [16].

SL competency has harmony with the process of Marzano's learning dimensions, on the competence to explain phenomena scientifically, evaluating and designing scientific investigations, and interpreting data and scientific evidence is very possible to be trained in the stages of the dimension of acquisition and integration of knowledge, expansion, and refinement of knowledge, as well as the stages of knowledge. Therefore students need to be introduced to how to develop knowledge scientifically and how to use that knowledge to make decisions, conduct investigations or to solve problems related to their lives [17].

\section{Methods}

Experimental research is one of the most powerful research methodologies that researchers can use [18]. The research design used in research is pre-experimental designs. In this research that is still outside variable that affects the dependent variable under research. Thus, the results of the experiment(the dependent variable) are not only influenced by the independent variable, but it also happens because there are no control variables and the sampling technique is not randomly chosen.

The pre-experimental designs used were one-group pretest-posttest designs. This design consisted of one experimental group that was given treatment and did not have a control class. Students in the experimental class were given a pretest $\left(\mathrm{O}_{1}\right)$, then given treatment and ended with a posttest $\left(\mathrm{O}_{2}\right)$. Improvement in students' scientific literacy competencies can be seen from the results of the pretest and posttest. Interpretation is given before the treatment is given, namely the assignment of reading assignments. After treatment is completed, students are given a posttest.

\section{Results and Discussion}

\subsection{Analysis of Learning Materials in class to train Scientific Literacy}

Related to the basic competency outlined in K13, related to the material of momentum, namely applying the concepts of momentum and impulses, as well as the law of conservation of momentum in daily life [19], and competency analysis of SL based on the Pisa 2018 framework [20], then the momentum material designed for high school students is divided into three parts. At the first meeting, the material is developed starting from the concept of the center 
of mass to momentum and impulses, by developing the topic of experiments determining the position of the center of the particle system. For the second meeting of the law of conservation of momentum, the law of conservation of kinetic energy, the coefficient of restitution and the type of collision, with the development of an experimental topic on the validity of the law of conservation of momentum. At the third meeting of the application of impulses as a change in momentum to derive the equation of rocket motion, the development of the experiment was related to analyzing the speed of the rocket's motion. The design of the material distribution can be explained in Table 1.

Based on Table 1, reading infusion is used to support the initial knowledge that students need to have so students can interact more quickly in the process of refinement of knowledge because with the knowledge gained through RI the inquiry process can build better[21]. The next step is to develop essential concepts through demonstration activities related to training the competency aspects of turning off competence in explaining scientific phenomena and evaluating competency aspects and designing scientific investigations, from presenting phenomena to designing procedures [22]. After together the student-teacher builds the students' procedures to take data, process data, analyze data and draw conclusions this activity trains aspects of competence in interpreting data and evidence scientifically.

Table 1. Content Present Design.

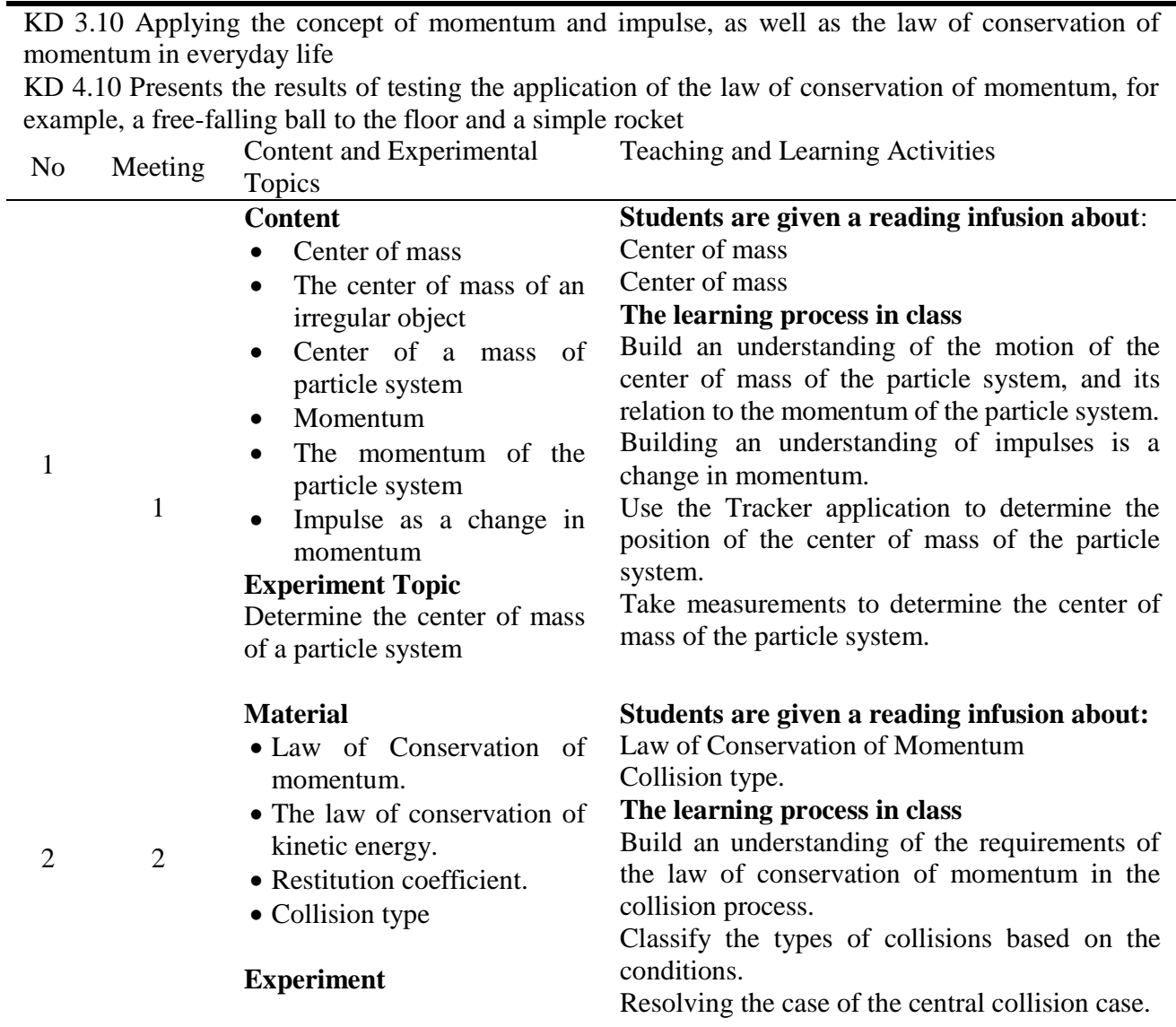


The law of conservation of Take a momentary velocity measurement to momentum applies to show the validity of the law of conservation of collisions. momentum.

\section{Content}

- Example type of collision

- The equation of rocket motion

- Apply the concept of momentum to the case of

33 physics

Students are given a reading infusion about: Decreased rocket equation of motion.

The concept of integration is needed to reduce the rocket equation.

\section{The learning process in class}

Classify the type of collision based on the conditions of the incident.

Reducing the equation of motion of the rocket based on the concept an impulse is a change in momentum.

Experiment

Determine rocket speed

Applying the concept of momentum to the case of simple physics.

Take a momentary velocity measurement on the rocket's motion.

\subsection{Changes in Didactic Design Based on Student Response}

To demonstrate competency in explaining scientific phenomena students must be able to remember material that is relevant to knowledge in a particular situation and (interpret data, explain phenomena, hypothesize, construct simpler representations to describe the possibility of change that will occur, describing and explaining a prediction). Therefore students need to be given reading infusion to get enough knowledge so that this competency can be well developed and has a positive perception.

Figure 2 shows some student responses that are difficult to develop and relate to the didactic design developed to facilitate SL competency. For aspects explaining scientific phenomena related to indicators: identity, use, produce models and clear representation.

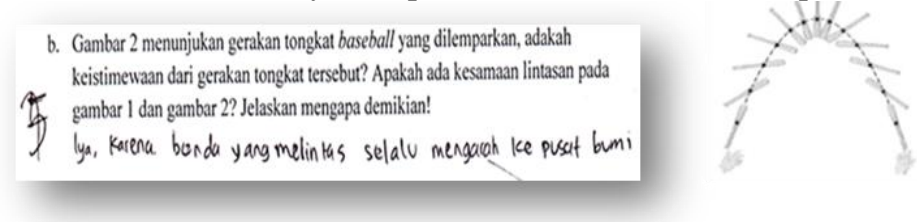

Fig. 2. Student ability to explain scientific phenomena.

Students can not identify using and producing a model that is representative and clear, then the didactic design changes made are developing knowledge in RI by explaining the motion of the center of mass representing the motion of a particle system as seen in Figure 3. 

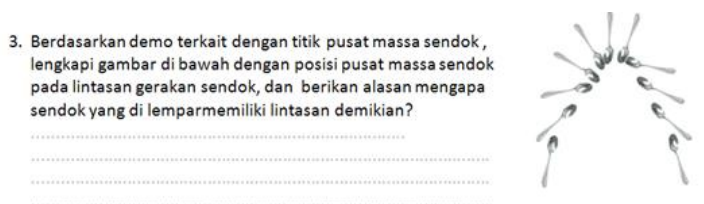

Fig. 3. Didactic design to improve students" understanding of the particle system.

We are relating to the response of scientific literacy competencies on aspects of evaluating and designing scientific investigations concerning indicators proposing ways to explore the questions given scientifically. Figure 4 is an example of students' responses regarding the above problems. Students can not explore inquiry questions, because students find it challenging to construct objects of phenomena that are present to observe the movement of the particle system to determine the motion of the center of mass by particles. The didactic design was repaired preceded by the following demonstration. The teacher shows broken objects in the air (capsules that are given per), then thrown in the air and video using the Tracker application as shown in Figure 5.

Students are asked to express how to get the position of the center of mass? Associated with aspects of competence are interpreting data and scientific evidence on indicators changing data from one representation to another. Based on the instruments developed students can turn the data representation of data tables into a depiction of the position of two particles that exploded in the air. As for the students' answers as seen in Figure 6.

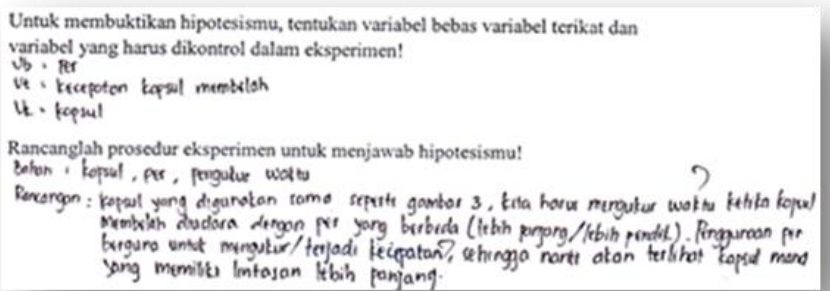

Fig. 4. The example of students' response regarding evaluating and designing scientific.
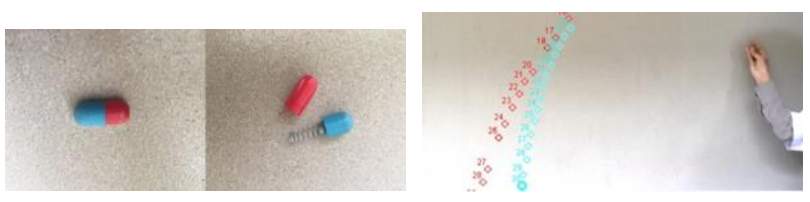

Fig. 5. Demonstration of momentum phenomena analyzed using Tracker.

Student responses showed that the data was still wrong because in reality that the data did not state the position of the center of mass of the particle system, but the video tracker would describe the phenomenon of particle position both before breaking and after breaking. Didactic design is built based on the aspects shown through the video tracker. Based on the phenomenon students must determine the position of particles before breaking, and after breaking, then students are asked to assess the image of the particle system. 


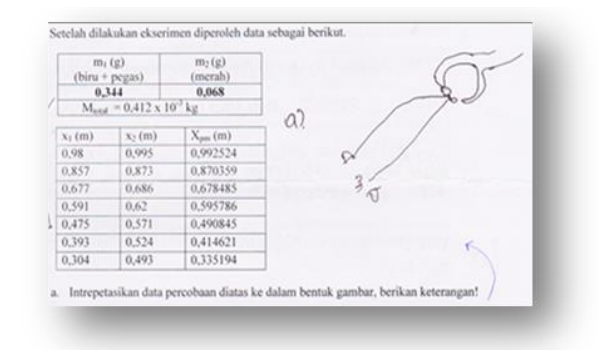

Fig. 6. Example of student ability in data and table analysis.

\section{Conclusion}

The didactic design of learning that facilitates SL is developed based on student responses and through Marzano's learning dimension, knowledge formation is obtained through reading infusion, refinement of knowledge through the inquiry process and the use of knowledge through the problem-solving laboratory of the given project.

Aspects of Competency Explaining scientific phenomena can be conveyed through the inquiry process starting from observation activities to offering hypotheses, aspects of evaluating and designing scientific research delivered through the design of procedures to obtain data and evaluating procedures based on investigative data, and aspects of interpreting data and scientific evidence can be trained through data processing techniques, representing data in different forms of representation providing analysis of data through arguments supported by data and concepts. For students to have positive perceptions (not easily frustrated), then all demonstrations, experiments given to facilitate SL must be tested first so that this process can facilitate productive thinking habits.

Acknowledgments. The author is very grateful to the Directorate of Higher Education for the funds that have been given for research and appreciate the help from various parties who have helped in making and finding information about writing this journal.

\section{References}

[1] OECD.: PISA 2018 Assessment and Analytical Framework, PISA, OECD Publishing, Paris, https://doi.org/10.1787/b25efab8-en (2019)

[2] Keefe and Copeland.: What Is Literacy? The Power of a Definition. Research \& Practice for Persons with Severe Disabilities online. Vol. 36, No. 3-4, pp. 92-99 (2011)

[3] Wenning.: Assessing nature-of-science literacy as one component of scientific literacy. Journal Physics Teachers Education. Vol. 3,No. 4 (2006)

[4] Hobson.: Thinking Habits into Action: the role of knowledge and process in questioning household consumption practices. Local Environment Vol. 8, No. 1, pp. 95-112 (2003)

[5] OECD.: PISA 2015 Result in Focus. https://puspendik.kemdikbud.go.id/tentang-pisa (2018).

[6] Arief and Utari.: Implementation of Levels of Inquiry on Science Learning To Improve. Jurnal Pendidikan Fisika Indonesia. Vol. 11, No. 2, pp. 117-119 (2015) 
[7] Utari, S., Nugraha, M.G., Saepuzaman, D., Setiawan A., and Prima, E.P.: Designing Science Learning for Training Students' Science Literacies at Junior High School Level, International Conference on Mathematics, Science, and Education (2015)

[8] Reza, R.: The Implementation of Levels of Inquiry With Writing-To-Learn Assignment To Improve Vocational School Student's Science Literacy, Journal of Physics: Conference Series, Volume 812, Issue 1, article id. 012049 (2017)

[9] Karim, S, Prima, E.C., Utari, S., Saepuzaman, D., and Nugraha, M.G.: Recostructing the Physics Teaching Didactic based on Marzano's Learning Dimension on Training the Scientific Literacies, Journal of Physics: Conf. Series 812. pp. 012102 (2017)

[10] Alrababah, F.E.A.: The Effectiveness Of Marzano's Dimensions Of Learning Model In The Tenth Grade Students Acquisition Of Scientific Concepts In Science And The Development Of Critical Thinking Skills And Their Attitude Towards Science. British Journal of Education. Vol.5, No.1. pp.7684 ( 2017)

[11] Nurmaulita.: Pembentukan Habits Of Mind Siswa Melalui Pembelajaran Salingtemas Pada Mata Pelajaran Fisika. Jurnal Pendidikan Fisika, Vol. 3 , No. 1 (2014)

[12] Manizar,Elly.: Peran Guru Sebagai Motivator Dalam Belajar. Jurnal Tadrib online. Vol. 1, No. 2 ,pp. 1-9 (2015)

[13] Mailani,I.: Implementasi Pendekatan Kontekstual Teaching and Learning dalam Pendidikan Agama Islam. Jurnal AL-HIKMAH Vol. 1, No 1, pp. 16-17

[14] Wattimena, H.S., Suhandi, A., Setiawan, A.,: Pengembangan Perangkat Perkuliahan Eksperimen Fisika Untuk Meningkatkan Kreativitas Mahasiswa Calon Guru Dalam Mendesain Kegiatan Praktikum Fisika Di SMA. Jurnal Pendidikan Fisika Vol. 10, No. 2 (2014)

[15] Abas and Hidayat.: Faktor-Faktor Kesulitan Belajar Fisika Pada Peserta Didik Kelas IPA Sekolah Menengah Atas. Jurnal Pendidikan Fisika online. Vol. 6 No. 1, pp. 45-49 (2016)

[16] Esi,Purwaningsih E., and Okianna : Peranan Guru Sebagai Fasilitator Dan Motivator Dalam Meningkatkan Hasil Belajar Di Kelas XI SMK. Jurnal Pendidikan dan Pembelajaran Khatulistiwa Untan Vol. 5, No. 10, pp. 1-3 (2016)

[17] Rustaman,N.: Trend Penelitian Pendidikan: Kasus Penelitian Pendidikan Sains. Seminar Nasional Pendidikan IPA.1-10 (2012)

[18] Fraenkel, J.R., Wallen, N.E. and Hyun, H.H.:How to Design and Evaluate Research and Education. McGraw-Hill ,New York (2012)

[19] Kemendikbud.:Lampiran Peraturan Mentri Pendidikan dan Kebudayaan No. 21 Tahun 2016 Tentang Standar Isi Pendidikan Dasar dan Menengah. http:bnsp-indonesia.org/wpcontent/uploads/2009/Permendikbud_Tahun2016) [5 september 2019] (2016)

[20] OECD.: PISA 2018 Assesstment and Analytical Framework, PISA, OECD Publishing, Paris, https://doi.org/10.1787/b25efab8-en (2019)

[21] Fang, Zhihui.: Improving Middle School Students' Science Literacy Through Reading Infusion. The Journal of Educational Research Vol. 103, No. 4, pp 262-273 (2010)

[22] Gormally, C., Brickman, P., Hallar, B., and Amstrong, N.,: Effects of Inkuiri-based Learning on Students' Science Literacy Skills and Confidence. International Journal for the Scholarship of Teaching and Learning. Vol. 3, No. 2. Article 16 (2009) 